\title{
Whitening Effect of Poria cocas Ethanol Extract by Inhibition of Melanin Synthesis
}

\author{
Hye-jung Park ${ }^{1}$, Eun-Jeong Kwon ${ }^{1}$, Moon-Moo Kim ${ }^{1}$, Lee Kyeong Rok ${ }^{2}$, Hong $\mathrm{il}^{2}$, Lee Do Gyeong ${ }^{2}$ \\ and Yunghee $\mathrm{Oh}^{1 *}$
}

\author{
${ }^{1}$ Department of Chemistry, Dong-Eui University, Busan 614-714, Korea \\ ${ }^{2}$ AMI cosmetics Mapo-gu, Seoul 121-888, Korea
}

Received December 13, 2013 /Revised February 17, 2014 /Accepted February 18, 2014

\begin{abstract}
Poria cocas has been reported to be effective in skin whitening. However, the direct effect of $P$. cocas ethanol extracts (PCEE) on melanin synthesis has not been scientifically studied. To elucidate the direct effect of PCEE on melanogenesis, a 3,4-dihydroxyindole-2-carboxylic acid (DOPA) synthesis assay, tyrosinase activity assay, and Western blotting for melanogenic proteins, including tyrosinase, tyrosinase-related protein (TRP)-1, and TRP-2 were performed in mouse B16F1 cells. The results revealed that PGEE inhibited melanin production in a dose-dependent manner by blocking the synthesis of DOPA. Although the activation of tyrosinase was not affected, the expression levels of TRP-1 and TRP-2 were controlled. These results suggest that PCEE has a whitening effect, indicating that it may be a useful agent in the development of whitening cosmetics.
\end{abstract}

Key words : B16F1, DOPA, Melanin, Poria cocas, tyrosinase-related protein (TRP)-1, TRP-2

\section{서 론}

피부 노화는 다양한 원인에 의해 진행되며, 그 중에서도 특 히 과도한 자외선 노출에 의한 피부노화를 광노화라고 부른 다[4, 15]. 자외선과 같은 외부자극이 피부에 가해지면, 기저 층에 있는 melanocyte가 유해한 자극으로부터 피부를 보호하 기 위한 방어기전으로써 melanin 합성을 유도한다[6]. 과도한 melanin의 생성은 기미, 주근깨, 일광성흑점, 과색소침착증 등의 색소침착을 야기한다. 특히 이러한 현상은 노화가 진행 될수록 더욱 심하게 나타난다. 체내의 melanin 생성은 다양한 기전에 의해 진행되지만 UV 노출에 의한 melanin 합성은 cyclic adenosine monophosphate (cAMP) / protein kinase A (PKA) 경로에 의해 합성된다[1]. 피부가 UV에 노출되면 melanocyte의 cAMP가 증가하여 신호물질인 $\mathrm{PKA}$ 를 활성화 한 다. PKA가 활성화 되면 cAMP response element binding protein (CREB)을 거쳐 melanin 합성 과정에서 중요한 전사 조절인자인 tyrosinase, TRP-1, TRP-2의 전사를 촉진시키는 $\mathrm{MITF}$ 의 발현이 증가된다[10,11,17]. 따라서 melanin의 합성 조절에 대한 연구가 많이 수행되었으며 특히 tyrosine을 3,4-dihydroxyphenylalanine (DOPA)로 전환하는 tyrosinase

\footnotetext{
*Corresponding author

Tel : +82-51-890-1517, Fax : +82-51-890-2620

E-mail : yhoh@deu.ac.kr

This is an Open-Access article distributed under the terms of the Creative Commons Attribution Non-Commercial License (http://creativecommons.org/licenses/by-nc/3.0) which permits unrestricted non-commercial use, distribution, and reproduction in any medium, provided the original work is properly cited
}

에 영향을 주는 요인에 초점이 맞춰져 있다. Tyrosinase는 tyrosine hydroxylase로 작용하여 tyrosine을 DOPA로 전환하 고, 뿐만 아니라 DOPA oxidase로도 작용하여 DOPA를 dopaquinone으로 전환하는 속도 결정단계의 초기반응에 작용하 여 melanin 합성을 돕는 효소이다[8]. 이러한 피부 노화는 melanin 축적 뿐 만 아니라 유해 활성산소종의 축적에 의해 서도 야기된다. 체내 항산화 효소계에 의해 제거되지 못한 유 해 활성산소종은 세포, 지질, protein, DNA 등에 손상을 주어 세포 및 진피 층의 주요 구성성분을 파괴하여 주름, 탄력저하 등을 야기한다[4]. 백복령은 진정작용과 이뇨작용, 항암활성, 항염증 활성 등에 효과 있다고 알려진 구멍쟁이 버섯과에 속 하는 진균류이다[16]. 뿐만 아니라 pachymic acid, 무기물, 당성분이 많이 함유되어 있어 혈액순환에도 도움이 된다고 알려져있다 $[9,12]$. 하지만 피부 미백에 관한 연구는 부족한 실정이다. 따라서 본 연구에서는 백복령의 피부 노화 개선효 과를 조사하기 위하여 melanin 합성 조절효과와 항산화 효과 를 조사하였다.

\section{재료 및 방법}

\section{재료 및 시료의 제조}

세포배양을 위한 Dulbecco's Modified Eagle's Medium (DMEM), Trypsin-EDTA, penicillin $(10,000 \mathrm{U} / \mathrm{ml})$ / streptomycin $(10,000 \mu \mathrm{g} / \mathrm{ml}) /$ amphotericin $(2,500 \mu \mathrm{g} / \mathrm{ml})$, fetal bovine serum (FBS) 시약은 Gibco BRL, Life Technologies (Paisley, Scotland)로 부터 구입하였다. B16F1 cell line은 ATCC (American Type Culture Collection, USA)로부터 구입 하였다. MTT reagent, gelatin, agarose와 기타시약은 Sigma 
Chemical Co. (St. Louis, MO, USA)로 부터 구입하였다.

\section{시료의 제조}

백복령 주정추출물(Poria cocas ethanol extract, PCEE)은 하 기와 같은 방법으로 추출하였다. 먼저, 백복령을 흐르는 물에 깨끗이 세척한 다음 완전히 자연 건조시켰다. 세척·건조된 상 기 백복령을 주정에 3 일간 추출하고 여과한 후, 여과된 여액을 감압 농축하여 분말 형태의 백복령 주정추출물을 얻는다. 제 조된 분말형태의 시료들을 시험농도로 희석하여 본 연구에 사용하였다.

\section{MTT assay}

Hansen [5]의 방법에 따라 B16F1 세포에 대한 PCEE의 세포 독성을 MTT (3-(4,5-dimethyl-2-yl)-2,5-diphenyltetrazolium bromide)를 이용하여 측정하였다.

\section{DPPH radical assay}

Brand-Williams [7] 실험방법을 변형하여 1,1-diphenyl2-picrylhydrazyl (DPPH) radical에 대한 PCEE의 소거능력을 측정하였다. 각 시료를 시험농도로 처리하고 10 초 동안 잘 혼 합한 다음, 실온에서 20 분 동안 반응시킨 후 $525 \mathrm{~nm}$ 에서 흡광 도를 측정하였다. $\mathrm{DPPH}$ radical 함량은 시료 첨가군과 대조군 의 흡광도 비를 \% 값으로 환산하여 나타내었다.

\section{환원력 Assay}

Oyaizu [13]의 방법에 따라 측정하였다. PCEE $1 \mathrm{ml}$ 에 $\mathrm{pH}$ 6.6 의 $200 \mathrm{mM}$ 인산 완충용액 및 $1 \%$ 의 potassium ferricyanide 를 각 $1 \mathrm{ml}$ 씩 차례로 가하여 교반 한 후 $50^{\circ} \mathrm{C}$ 의 수욕상에서 20 분 동안 반응시켰다. 여기에 $10 \% \mathrm{TCA}$ 용액 $1 \mathrm{ml}$ 를 가하여 $13,500 \times \mathrm{g}$ 에서 15 분 동안 원심분리하여 얻은 상등액 $1 \mathrm{ml}$ 에 증류수 및 ferric chloride 각 $1 \mathrm{ml}$ 를 가하여 혼합한 후 700 $\mathrm{nm}$ 에서 흡광도를 측정하였다. 양성 대조군으로 $0.01 \%$ vita$\min C$ 를 사용하였다. 시료의 환원력은 시료 첨가군와 대조군 의 흡광도 비를 \% 값으로 환산하여 나타내었다.

\section{In vitro 지질과산화에 대한 항산화 활성(TBARS)}

$\mathrm{PCEE}$ 를 시험농도가 되게 linolenic acid emulsion과 30분 동안 혼합한 후 $0.8 \mathrm{mM} \mathrm{H} \mathrm{O}_{2}$ 및 $0.8 \mathrm{mM} \mathrm{FeSO}$ 를 혼합한 용액을 5 시간 동안 반응 시킨 후 $0.4 \% \mathrm{TBA}$ 를 첨가하고 $95^{\circ} \mathrm{C}$ 에 서 2시간 동안 반응시켜 실온에서 10 분 동안 반응시켰다. 그 다음, $15: 1$ 비율의 n-butanol : pyridine 용액을 $500 \mu l$ 첨가하고 $1,000 \times \mathrm{g}$ 에서 10 분 동안 원심분리하여 상등액을 $532 \mathrm{~nm}$ 에서 흡광도를 측정하였으며 지질과산화 정도는 시료 첨가 전후의 흡광도 비를 \%값으로 환산하였다.

\section{In vitro tyrosinase 활성 측정}

시험관에 $0.1 \mathrm{M}$ 인산염완충액 $(\mathrm{pH}$ 6.5) $220 \mu \mathrm{l}$ 와 시료액 20 $\mu \mathrm{l}$ 그리고 mushroom tyrosinase $(1500 \mathrm{U} / \mathrm{ml})$ 액 $20 \mu \mathrm{l}$ 를 순서 대로 넣는다. 이 용액에 $1.5 \mathrm{mM}$ tyrosine 액 $40 \mu \mathrm{l}$ 를 넣고 $37^{\circ} \mathrm{C}$ 에서 $10 \sim 15$ 분 동안 반응시킨다. 그리고 이것을 ELISA reader (ELISA processor II. Behring,Germany)를 이용하여 $490 \mathrm{~nm}$ 에서 흡광도를 측정하였다.

\section{$\mathrm{B} 16 \mathrm{~F} 1$ 에서 Melanin 생성 측정}

6-well plate에 $3 \times 10^{5}$ cells/well로 세포를 분주하였고, 시료 를 처리하고 1시간 후에 L-DOPA로 melanin 생성을 자극 후 48시간 동안 세포를 배양 하였다. 세포를 수집하여 1,200rpm 에서 5 분간 원심 분리하여 침전한 후, $1 \mathrm{ml}$ homogenization buffer (50 mM sodium phosphate $\mathrm{pH}$ 6.5, 1\% Triton X-100, $2 \mathrm{mM}$ phenyl methyl sulfonyl fluoride)로 용해시켰다. 여기 서 얻은 pellet에 $1 \mathrm{~N} \mathrm{NaOH}(10 \%$ DMSO) $200 \mu \mathrm{l}$ 를 첨가하고 vortex 후 $405 \mathrm{~nm}$ 에서 흡광도를 측정 하였다. melanin 표준품 (Sigma, USA)으로 얻은 표준 검량선을 이용하여 각 well에 서 생성된 멜라닌 양을 산출하였다. 멜라닌은 단위세포 $\left(10^{4}\right.$ cells)에서의 멜라닌 생성량을 비교하였다.

\section{세포배양}

$\mathrm{B} 16 \mathrm{~F} 1$ 세포는 $5 \% \mathrm{CO}_{2}$ 및 $37^{\circ} \mathrm{C}$ 에서 $95 \%$ 이상의 습도를 유 지한 배양기에서 $10 \%$ fetal bovine serum, $2 \mathrm{mM}$ glutamine과 $100 \mu \mathrm{g} / \mathrm{ml}$ penicillin-streptomycin을 포함하는 Dulbecco's modified Eagle's medium (DMEM) 배지에서 배양하였다.

\section{Western blot analyses}

$\mathrm{B} 16 \mathrm{~F} 1$ 세포에 용출 완충용액 $(50 \mathrm{mM}$ Tris - $\mathrm{HCl}, \mathrm{pH} 7.5$, $0.4 \%$ Nonidet P-40, $120 \mathrm{mM} \mathrm{NaCl}, 1.5 \mathrm{mM} \mathrm{MgCl}, 2 \mathrm{mM}$ phenylmethylsulfonyl fluoride, $80 \mu \mathrm{g} / \mathrm{mL}$ leupeptin, $3 \mathrm{mM}$ $\mathrm{NaF}$ and $1 \mathrm{mM} \mathrm{DTT}$ )을 첨가하여 $4^{\circ} \mathrm{C}$ 에서 30 분 동안 처리하였 다. $10 \mu \mathrm{g}$ 의 세포용출액을 $10 \%$ Tris $-\mathrm{HCl}$ gel에서 전기영동 후 단백질을 전기적으로 nitrocellulose membrane으로 전이 시켰다. 그 다음 $10 \%$ skim milk를 nitrocellulose membrane에 전처리하고 목적 단백질에 대한 1차 항체(anti-tyrosinase, anti-TRP -1, anti-TRP -2, anti-SOD -1, anti-beta-actin (Santa Cruz Biotechnology Inc., Santa Cruz, USA))를 처리한 다음 2차 항체를 처리 후, chemiluminescent ECL kit (Amersham Pharmacia Biotech, Piscataway, USA)를 사용하여 목적단백 질을 검출하였다. Western blot의 band는 LAS3000 ®image analyzer (Fuji film Life Science, Tokyo, Japan)를 이용하여 관찰하였다.

\section{통계처리}

각 실험은 3 회 이상 반복실험을 통하여 그 결과를 얻어 각각 
의 시료농도에 대해 평균표준편차로 나타내었다. 각 시료농 도군에 대한 유의차 검정은 대조군과 비교하여 Student's $t$ test 한 후 $p \times 0.05$ 값을 통계적으로 유의성 있는 결과로 간주하였다.

\section{결 과}

\section{세포성장에 대한 PCEE의 효과}

이 세포 독성에 미치는 농도를 조사하기 위하여 MTT assay 를 수행하였다. B16F1세포에 대한 각 시료의 세포 독성을 측정 한 결과, Fig. 1에서 보는 바와 같이 PCEE는 $3.12 \mu \mathrm{g} / \mathrm{ml}$ 이하 의 농도에서 대조군과 비교하였을 때 어떠한 독성효과도 없는 것으로 나타났다.

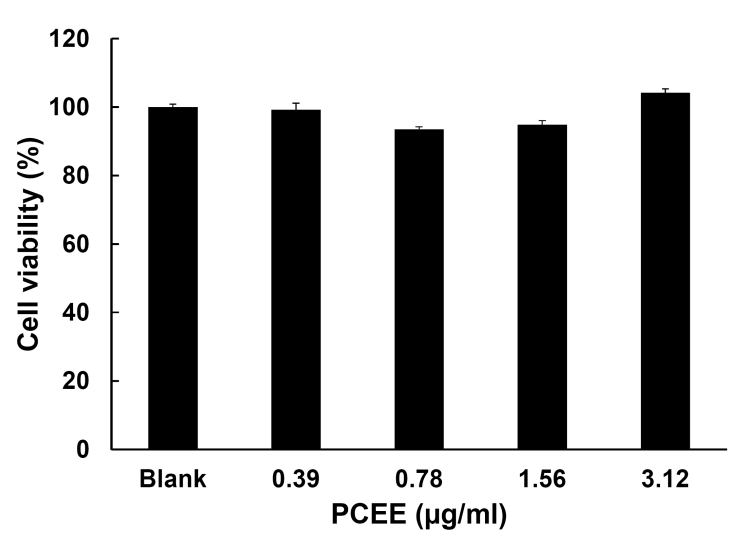

Fig. 1. Effect of PCEE on viability in B16F1 cells. The cells were treated with PCEE at $0.39,0.78,1.56$ and $3.12 \mu \mathrm{g} / \mathrm{ml}$. Cell viability was determined by MTT assay after $24 \mathrm{hr}$. Data are given as means of values \pm S.D. from three independent experiments. Level of significance was identified statistically using Student's $t$ test.

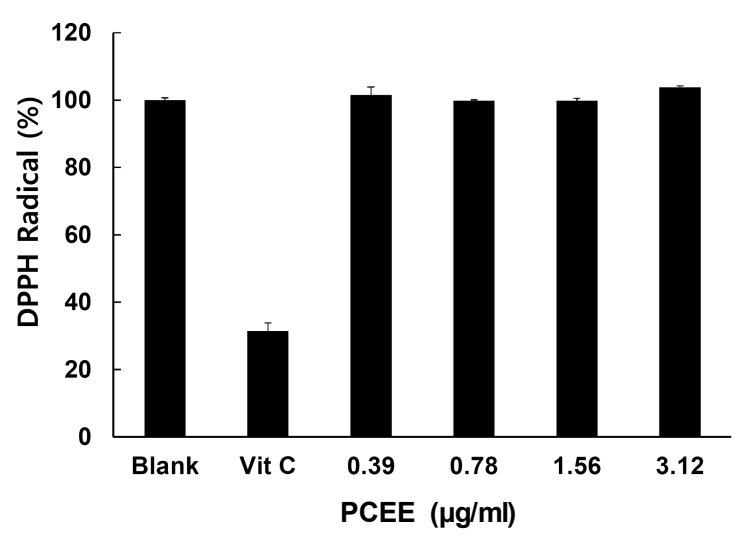

Fig. 2. DPPH radical Scavenging effect of PCEE. Vitamin C (Vit C) at $100 \mu \mathrm{g} / \mathrm{ml}$ was used as a positive control. Data are given as means of values \pm SD from three independent experiments. Level of significance was identified statistically $\left({ }^{* * *}, p<0.001\right)$ using Student's $t$ test.

\section{DPPH radical에 대한 PCEE의 효과}

DPPH radical, lipid peroxidation 의 소거능력에 대하여 $\mathrm{PCEE}$ 의 효과를 조사하였다. DPPH radical소거법은 항산화 물 질에 의한 $\mathrm{DPPH}$ radical의 탈색 정도를 지표로 하여 산화억제 정도를 예측할 수 있다. Fig. 2에서 보는 바와 같이 PCEE를 처리 한 그룹의 DPPH radical에 대한 소거능은 나타나지 않았다.

\section{Lipid peroxidation에 대한 PCEE의 효과}

백복령의 지질과산화 억제능을 조사하기 위하여 TBARS assay를 수행하였다. Fig. 3에서 보는 바와 같이 양성 대조군으 로 사용된 vitamin E $0.1 \%$ 는 약 $20 \%$ 의 억제능을 나타낸 반면, $\mathrm{PCEE}$ 는 유효성 있는 억제효과를 나타내지 않았다.

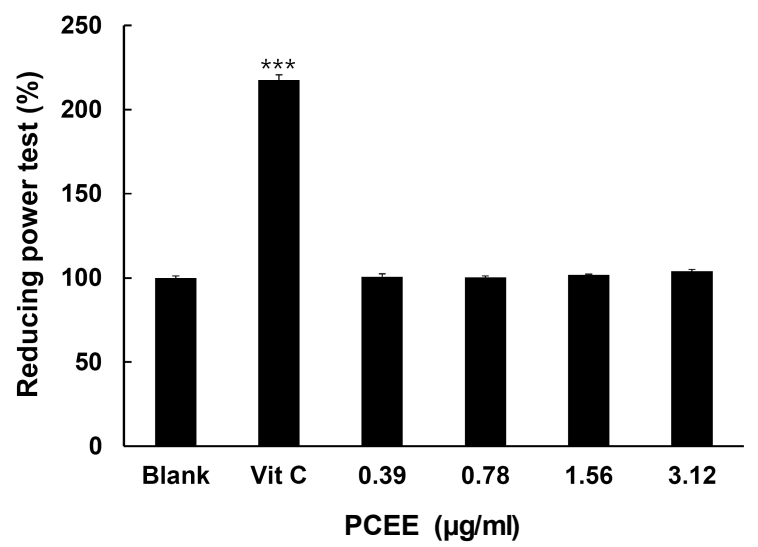

Fig. 3. Reducing power of PCEE. Vitamin C (Vit C) at $10 \mu \mathrm{g} / \mathrm{ml}$ was used as a positive control. Data are given as means of values \pm SD from three independent experiments. Level of significance was identified statistically (***, $p<0.001)$ using Student's $t$ test.

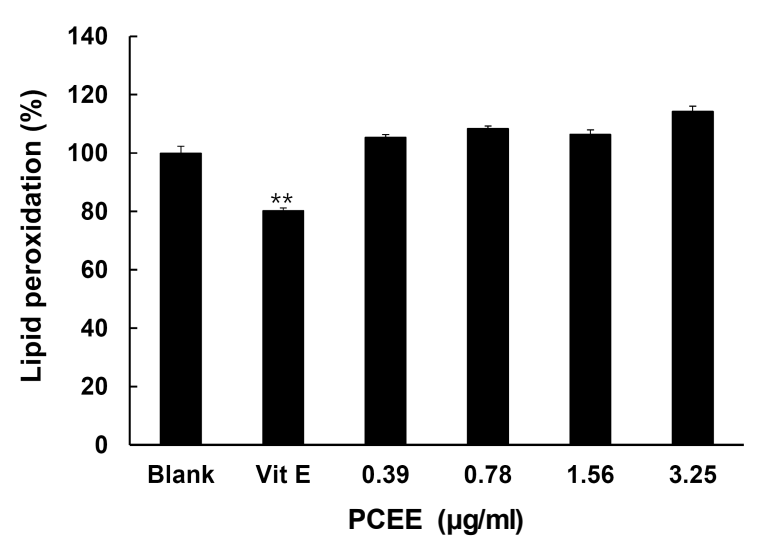

Fig. 4. Inhibitory effect of PCEE on lipid peroxidation. Lipid peroxidation was determined by TBARS. Vitamin E (Vit E) at $1000 \mu \mathrm{g} / \mathrm{ml}$ was used as a positive control. Data are given as means of values \pm S.D. from three independent experiments. Level of significance was identified statistically $\left(^{* *} p<0.01\right)$ using Student's $t$ test. 


\section{Reducing power에 대한 PCEE의 효과}

백복령의 환원력을 조사하기 위해 potassium ferricyanide 와 ferric chloride를 이용하여 환원력을 조사하였다. Fig. 4에 서 보는 바와 같이 양성 대조군으로 사용된 $0.01 \%$ 의 농도의 vitamin C는 약 $117 \%$ 의 환원력을 나타낸 반면, PCEE는 3.12 $\mathrm{\mu g} / \mathrm{ml}$ 이하의 농도에서 환원력이 나타나지 않았다.

\section{In vitro tyrosinase 활성억제에 대한 $\mathrm{PCEE}$ 의 효과}

Tyrosinase는 인체내의 멜라닌 생합성 경로에서 가장 중요 한 초기 속도결정단계에 관여하는 효소로서 많은 미백 성분이 이 효소를 억제하는 작용기전을 가지고 있다. 이 시험은 in vitro에서 tyrosinase의 활성을 저해하는 정도를 평가할 수 있 다. Fig. 5에서 보는 바와 같이 PCEE는 억제효과를 나타내지 않았다. 양성 대조군으로는 $2,000 \mu \mathrm{gg} / \mathrm{ml}$ 의 arbutin이 사용되 었다.

\section{$\mathrm{B} 16 \mathrm{~F} 1$ 에서 Melanin 생성 조절에 대한 PCEE의 효과}

DOPA자극을 통한 melanin 생성조절효과를 조사하기 위 해 B16F1 세포를 사용하여 melanin 함량을 측정 하였다. Fig. $6 \mathrm{~A}$ 에서 보는 바와 같이 $\mathrm{PCEE}$ 는 $3.12 \mathrm{\mu g} / \mathrm{ml}$ 농도이상에서 melanin 생성이 대조군에 비해 9\%가 억제되었다. 그리고 세포 내에 melanin 생성양을 측정하기 위해 $1 \mathrm{~N} \mathrm{NaOH}$ 를 이용하여 세포내 melanin을 측정한 결과 Fig. 6B에서 보는 바와 같이 PCEE는 $0.39 \mathrm{\mu g} / \mathrm{ml}$ 이상의 농도에서 melanin 합성을 $25 \%$ 이 상 억제 시켰다. 본 실험에서 양성대조군을 사용된 $2000 \mu \mathrm{g} /$ $\mathrm{ml}$ 의 arbutin은 melanin 합성을 $25 \%$ 억제 시켰다.

$\mathrm{B} 16 \mathrm{~F} 1$ 세포에서 미백과 항산화 효과와 관련된 단백질의 발현에 대한 $\mathrm{PCEE}$ 의 효과

Melanin 생성의 중요한 효소인 tyrosinase와 melanin 생성

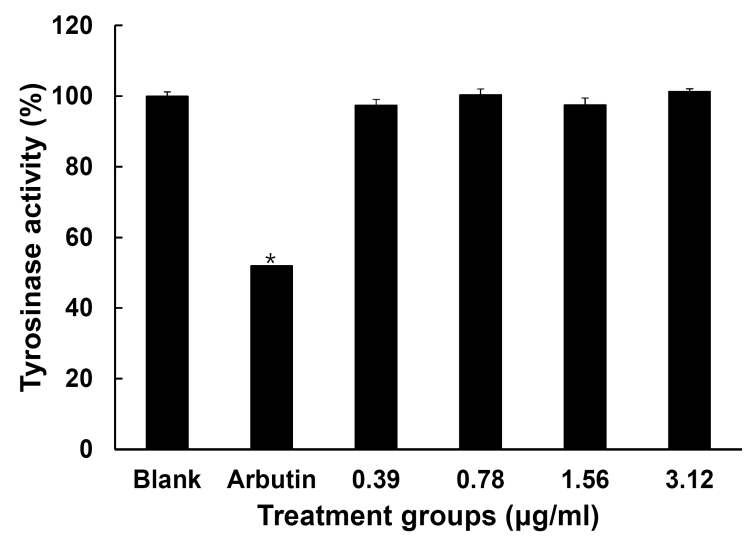

Fig. 5. Effect of PCEE on tyrosinase activity. Arbutin $2000 \mu \mathrm{g} / \mathrm{ml}$ was used as a positive control. Data are given as means of values \pm S.D. from three independent experiments. Level of significance was identified statistically using Student's $\mathrm{t}$ test.
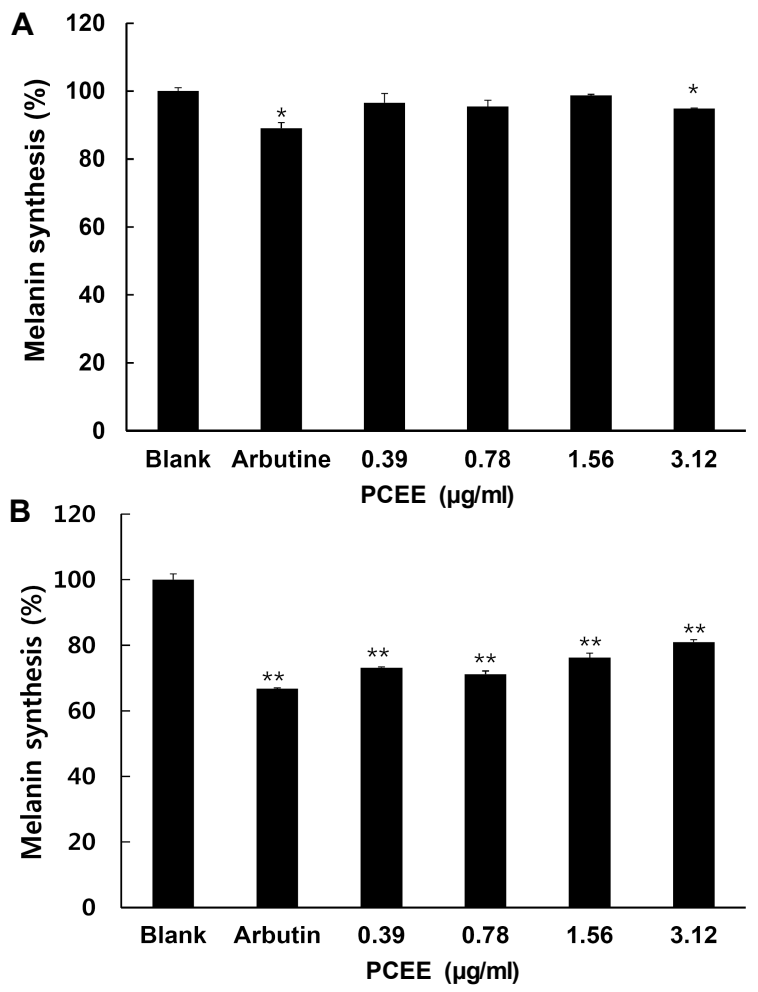

Fig. 6. Effect of PCEE on melanin synthesis in B16F1. The amount of extracellular melanine (A) and intracellular melanin (B) were analyzed in B16F1 cells treated with PCEE. Arbutin $2000 \mu \mathrm{g} / \mathrm{ml}$ was used as a positive control. Data are given as means of values \pm S.D. from three independent experiments. Level of significance was identified statistically ( $\left.{ }^{*} p<0.05\right)$ using Student's $\mathrm{t}$ test.

신호전달기전에 중요한 tyrosinase related protein-1 (TRP-1), tyrosinase related protein-2 (TRP-2)와 항산화 효소 중에서 가장 중요한 superoxide dismutase (SOD)인 SOD-1의 단백질 발현을 조사하였다. Fig. 7에서 보는 바와 같이 PCEE는 SOD-1 의 단백질 발현을 감소시키는 것으로 나타났으나 tyrosine을 $\mathrm{DOPA}$ 로 전환하는 tyrosinase의 단백질 발현에는 아무런 영향 도 미치지 않았다. 반면 DOPA 자극하에서 TRP-1의 단백질 발현은 감소되었으며 PCEE 처리하에서 다시 공시험과 같은 수준의 발현수준을 유지하였다. dopachrom을 산화시켜 5,6dihydroxyindole-2-carboxylic acid (DHICA)를 생성시키는 $\mathrm{PCEE}$ 는 $6.25 \mu \mathrm{g} / \mathrm{ml}$ 의 농도에서 TRP-2의 단백질 발현수준을 억제시키는 것으로 나타났다.

\section{고 찰}

자외선으로부터 피부를 보호하기 위해 생성되는 melanin 은 광노화 현상으로부터 피부를 보호하지만 과량이 생성되어 제거되지 못하면 기미, 주근깨, 색소침착 등을 야기시킨다[2]. 


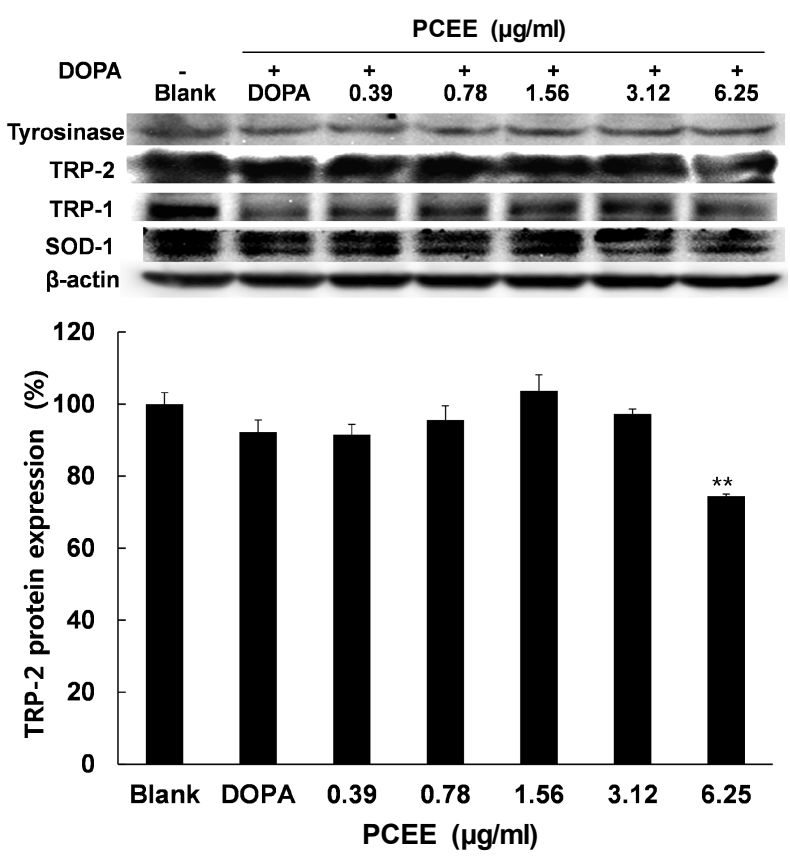

Fig. 7. Effect of PCEE on protein expressions of TRP-1, TRP-2, tyrosinase, SOD-1 in B16F1 cells. The cells were treated with PCEE at $0.39,0.78,1.56,3.12$ and $6.25 \mu \mathrm{g} / \mathrm{ml}$. Western blot analysis of cell lysates was performed using antibodies as indicated. Level of significance was identified statistically $\left({ }^{* *} p<0.01\right)$ using Student's $t$ test.

따라서 과도한 melanin의 생성과 축적은 오히려 피부노화의 하나의 현상으로 간주된다. 광노화의 원인 중 한가지인 ROS 의 축적 억제효과와 melanin 합성 억제 효과를 조사하여 백복 령이 미백기능성 화장품으로써 적합한가를 조사하였다. 본 연 구는 피부 진피층에서 melanin을 합성하는 melanocyte의 한 종류인 B16F1 cell에 대해 독성이 없는 농도에서 진행되었다. PCEE의 ROS 소거능을 조사하기 위해 DPPH radical assay, reducing power test, TBARS를 수행한 결과 PCEE은 어떠한 항산화 효과도 나타내지 않았다. 따라서 PCEE은 ROS에 대한 소거능은 없는 것으로 간주되며 이를 통한 피부의 미백기능 및 피부노화 억제 효과는 나타내지 않을것으로 간주된다. 하 지만 PCEE의 피부 미백효과를 조사하기 위해 melanin 합성에 있어 중요한 역할을 하는 tyrosinase 활성측정과 DOPA assay 를 수행한 결과 tyrosinase 활성억제에 대한 효과는 나타내지 않았으나 DOPA 합성 억제능은 현재 널리 사용되어지고 있는 미백제인 arbutin $0.2 \%$ 와 비슷한 수준인 $25 \%$ 의 억제능을 타내 었다. 이는 PCEE가 체내에 melanin이 합성되는 과정인 tyrosine이 tyrosinase에 의해 3,4-dihydroxyphenylalanine (DOPA)로 전환되는 과정에서 tyrisonase 활성에는 아무런 영 향을 나타내지 못했으나, DOPA 합성을 억제함으로써 미백효 과를 나타내는 것을 의미한다[14]. PCEE의 DOPA 합성 억제 효과를 보다 자세히 조사하기 위해 western blot을 이용하여 단백질 발현 수준을 조사하였다. DOPA 자극 하에서 PCEE를
B16F1 cells에 처리하여 tyrosinase의 단백질 발현 수준을 조사 하였다. 그 결과 tyrosinase의 단백질 발현 수준은 일정하게 나타나 이전의 연구결과와 일치하였다. 하지만 흥미롭게도 DOPA 자극 하에서 B16F1 cells는 매우 낮은 수준의 TRP-1 단백질 발현을 나타냈다. 이는 체내 melanin이 항상성 잇게 유지되기 위함으로 사료된다. TRP-1은 DHICA를 산화시켜 최 종적으로 melanin을 생성하는 DHICA oxidase로 melanin 생 성에 있어 매우 중요한 역할을 하는 단백질 중 하나이다[3]. $\mathrm{DOPA}$ 자극 하에서 PCEE를 농도에 따라 처리한 결과 TRP-1 의 단백질 발현수준은 농도의존적으로 증가하였다. 과량의 DOPA로 인해 TRP-1의 단백질 발현이 매우 낮게 유지되는 상태에서 PCEE 처리에 의한 TRP-1 단백질 발현 증가는 매우 의미심장한 의미를 내포하고 있다. 이는 PCEE가 유의적으로 $\mathrm{DOPA}$ 를 제거하였기 때문에 세포에서 TRP-1의 생성이 정상 수준으로 돌아간 것이라고 사료되어진다. 또한 dopachrom을 산화시켜 $\mathrm{DHICA}$ 를 생성시키는 고농도의 $\mathrm{PCEE}$ 존재하에서 TRP-2의 단백질 발현수준이 억제되는 것을 확인하였다. 따라 서 PCEE는 tyrosinase의 효소활성을 직접적으로 억제시키지 는 않지만, tyrosine에서 melanin으로 전환되는 다단계 과정 중에서 반응의 초기단계인 $\mathrm{DOPA}$ 로의 전환을 효과적으로 저 해하여 melanin의 합성을 억제하는 것으로 사료된다. 이러한 $\mathrm{PCEE}$ 의 피부미백 효과를 통해 백복령이 미백 기능성 화장품 으로써 활용가치가 높을 것으로 기대된다.

\section{감사의 글}

본 논문은 교육과학기술부의 재원으로 지원을 받아 수행된 산학협력 선도대학(LINC) 육성사업, 중소기업청에서 지원하 는 2013년도 산학연협력 기술개발사업(No.C0149500) 및 2014 학년도 동의대학교 교내연구비에 의해 연구되었음(2014AA262).

\section{References}

1. BALLOTTI, R. 2000. Cyclic AMP a key messenger in the regulation of skin pigmentation. Pigment Cell Res 13, 60-69.

2. Berneburg, M., Plettenberg, H. and Krutmann, J. 2000. Photoaging of human skin. Photodermatol Photoimmunol Photomed 16, 239-244.

3. del Marmol, V. and Beermann, F. 1996. Tyrosinase and related proteins in mammalian pigmentation. FEBS Lett 381, 165-168.

4. Fisher, G. J., Kang, S., Varani, J., Bata-Csorgo, Z., Wan, Y., Datta, S. and Voorhees, J. J. 2002. Mechanisms of photoaging and chronological skin aging. Arch Dermatol 138, 1462-1470.

5. Hansen, M. B., Nielsen, S. E. and Berg, K. 1989. Re-examination and further development of a precise and rapid dye method for measuring cell growth/cell kill. J Immunol Methods 119, 203-210.

6. Herrling, T., Jung, K. and Fuchs, J. 2007. The important role 
of melanin as protector against free radicals in skin. Spectrochim Acta A Mol Biomol Spectrosc 133, 26-32.

7. Imai, J., Ide, N., Nagae, S., Moriguchi, T., Matsuura, H. and Itakura, Y. 1994. Antioxidant and radical scavenging effects of aged garlic extract and its constituents. Planta Med 60, 417-420.

8. Iozumi, K., Hoganson, G. E., Pennella, R., Everett, M. A. and Fuller, B. B. 1993. Role of tyrosinase as the determinant of pigmentation in cultured human melanocytes. I Invest Dermatol 100, 806-811.

9. Jin, Y., Zhang, L., Zhang, M., Chen, L., Keung Cheung, P. C., Oi, V. and Lin, Y. 2003. Antitumor activities of heteropolysaccharides of Poria cocos mycelia from different strains and culture media. Carbohydr Res 338, 1517-1521.

10. Kim, D. S., Kim, S. Y., Chung, J. H., Kim, K. H., Eun, H. C. and Park, K.-C. 2002. Delayed ERK activation by ceramide reduces melanin synthesis in human melanocytes. Cell Signal 14, 779-785.

11. Kim, D. S., Park, S. H., Kwon, S. B., Kwon, N. S. and Park, K. C. 2010. Sphingosylphosphorylcholine inhibits melanin synthesis via pertussis toxin sensitive MITF degradation. J Pharm Pharmacol 62, 181-187.

12. Lee, K. Y. and Jeon, Y. J. 2003. Polysaccharide isolated from
Poria cocos sclerotium induces NF-kB/Rel activation and iNOS expression in murine macrophages. Int Immunopharmacol 3, 1353-1362.

13. Oyaizu, M. 1986. Studies on products of browning reaction--antioxidative activities of products of browning reaction prepared from glucosamine. Jap J Ntr Dia 44, 307-315.

14. Slominski, A., Tobin, D. J., Shibahara, S. and Wortsman, J. 2004. Melanin pigmentation in mammalian skin and its hormonal regulation. Physiol Rev 84, 1155-1228.

15. Wenk, J., Brenneisen, P., Meewes, C., Wlaschek, M., Peters, T., Blaudschun, R., Ma, W., Kuhr, L., Schneider, L. and Scharffetter-Kochanek, K. 2011. UV-induced oxidative stress and photoaging. Curr Probl Dermatol 29, 83-94.

16. Wu, S. J., Ng, L. T. and Lin, C. C. 2004. Antioxidant activities of some common ingredients of traditional chinese medicine, angelica sinensis, lycium barbarum and Poria cocos. Phytother Res 18, 1008-1012.

17. Yasumoto, K. i., Yokoyama, K., Takahashi, K., Tomita, Y. and Shibahara, S. 1997. Functional analysis of microphthalmia-associated transcription factor in pigment cellspecific transcription of the human tyrosinase family genes. J Biol Chem 272, 503-509.

\title{
초록 : 백복령 주정 추출물의 멜라닌합성 억제를 통한 미백효과
}

\author{
박혜정 ${ }^{1} \cdot$ 권은정 ${ }^{1} \cdot$ 김문무 ${ }^{1} \cdot$ 이경록 $^{2} \cdot$ 홍 $^{\text {일 }} \cdot$ 이도경 $^{2} \cdot$ 오영희 $^{1 *}$ \\ ('동의대학교 화학과, ${ }^{2}$ (주)아미코스메틱)
}

백복령(Poria cocas)은 전통적으로 민간에서 피부미백에 효과가 있다고 보고되어 있다. 지금까지 melanin 합성 에 대한 백복령의 직접적인 효과는 과학적으로 잘 연구되어 있지 않다. 따라서 멜라닌 합성에 대한 백복령 주정 추출물(PCEE)의 직접적인 효과를 밝히기 위해, 쥐의 $\mathrm{B} 16 \mathrm{~F} 1$ 세포를 이용하여 DOPA synthesis assay, tyrosinase activity assay, Western blotting for melanogenic proteins [tyrosinase, tyrosinase related protein (TRP)-1 and TRP-2]를 수행하였다. 본 연구에서 PCEE가 3,4-dihydroxyindole-2-carboxylic acid (DOPA) 합성을 차단함으로써 농도 의존적으로 melanin형성을 억제한다는 것이 밝혀졌다. 비록 tyrosinase의 활성은 영향을 받지 않았지만 TRP-1 과 TRP-2의 단백질 발현 수준은 PCEE에 의해 조절되었다. 따라서 이러한 결과는 PCEE가 미백 효능을 가 지고 있어 미백 화장품 개발을 위해 이용될 수 있다는 것을 시사하고 있다. 